\title{
2002 Assessment of Undiscovered Oil and Gas Resources of the Jurassic-Cretaceous Cotton Valley Group, Jurassic Smackover Interior Salt Basins Total Petroleum System, in the Louisiana-Mississippi Salt Basins Province of the Northern Gulf Coast Region
}

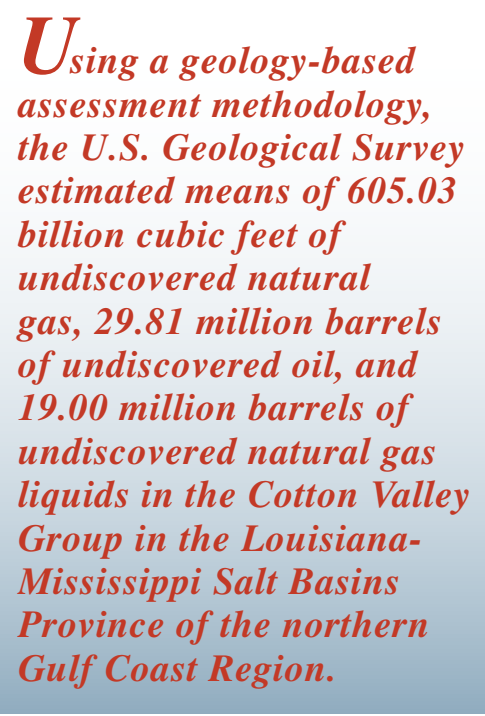

Figure 1. Map of Louisiana-Mississippi Salt Basins Province 5049 and East Texas Basin Province 5048 of the Gulf Coast region showing geographic distribution of the Cotton Valley Group assessment units in the Jurassic Smackover Interior Salt Basins Total Petroleum System.

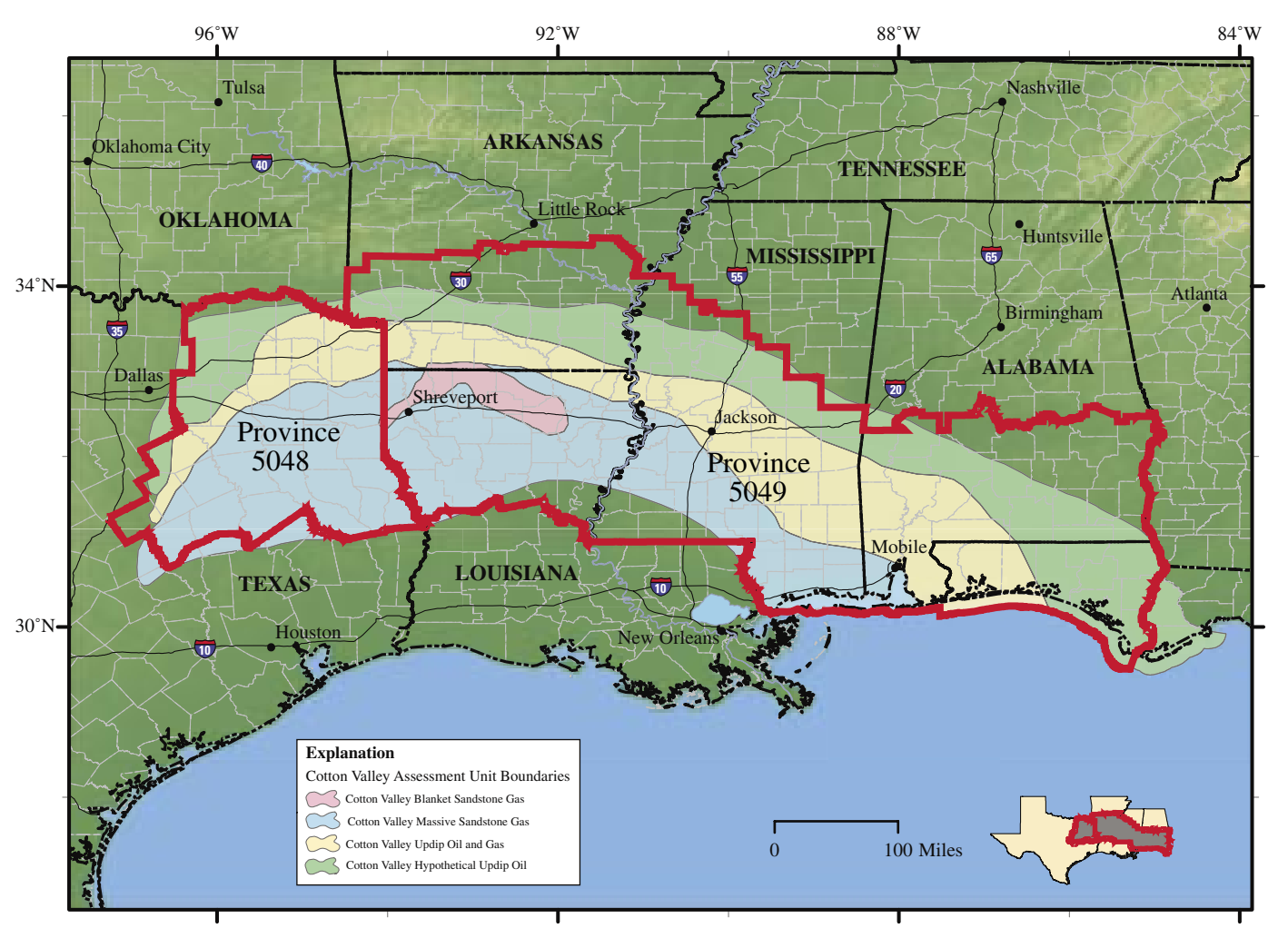

\section{Introduction}

The U.S. Geological Survey (USGS) recently completed an assessment of the undiscovered oil and gas potential of the JurassicCretaceous Cotton Valley Group in the Louisiana-Mississippi Salt Basins Province of the northern Gulf Coast Region (fig. 1) as part of a national oil and gas assessment effort. For assessment purposes, the East Texas Basin Province was included with the LouisianaMississippi Salt Basins Province. The assessment of the petroleum potential of the Cotton Valley Group was based on the general geologic elements used to define a total petroleum system (TPS), which include hydrocarbon source rocks (source rock maturation, hydrocarbon generation and migration), reservoir rocks (sequence stratigraphy and petrophysical properties), and hydrocarbon traps (trap formation and timing). Using this geologic framework, the USGS defined four assessment units (AU) that are included in one TPS, the Jurassic Smackover Interior Salt Basins TPS: Cotton Valley Blanket Sandstone Gas AU, Cotton Valley Massive Sandstone Gas AU, Cotton Valley Updip Oil and Gas AU, and Cotton Valley Hypothetical Updip Oil AU.

\section{Resource Summary}

The USGS assessed undiscovered conventional oil and gas for each of the AUs, resulting in estimated means of 605.03 billion cubic feet of non-associated gas and associated gas in oil fields, 29.81 million barrels of oil, and 19.00 million barrels of natural gas liquids in the Jurassic Smackover Interior Salt Basins TPS (table 1). All of the undiscovered gas is conventional. The Cotton Valley Massive Sandstone Gas AU contains 547.25 billion cubic feet of gas, representing about 90 percent of the total mean undiscovered gas resource (605.03 billion cubic feet) for the Cotton Valley Group in the province. The Bossier Shale TPS of the lower Cotton Valley Group was not quantitatively assessed for this study. 
Table 1. Cotton Valley Group assessment results for the Jurassic Smackover Interior Salt Basins Total Petroleum System.

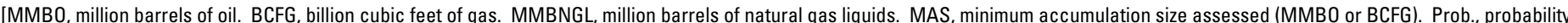

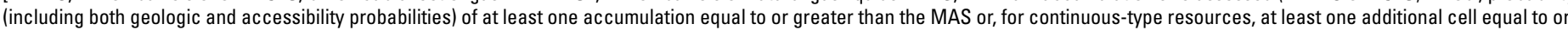

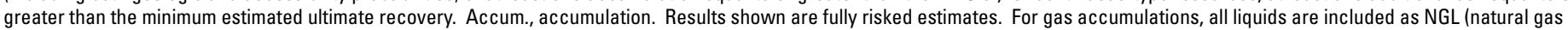

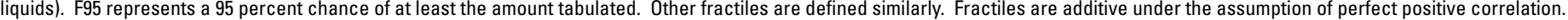
Shading indicates not applicable]

\begin{tabular}{|c|c|c|c|c|c|c|c|c|c|c|c|c|c|c|}
\hline \multirow{3}{*}{$\begin{array}{c}\text { Accumulation } \\
\text { Type }\end{array}$} & \multirow{3}{*}{ MAS } & \multirow{3}{*}{$\begin{array}{r}\text { Prob. } \\
(0-1)\end{array}$} & \multicolumn{12}{|c|}{ Total Undiscovered Resources } \\
\hline & & & \multicolumn{4}{|c|}{ Oil (MMBO) } & \multicolumn{4}{|c|}{ Gas (BCFG) } & \multicolumn{4}{|c|}{ NGL (MMBNGL) } \\
\hline & & & F95 & $\mathrm{F} 50$ & $\mathrm{~F} 5$ & Mean & F95 & $\mathrm{F} 50$ & F5 & Mean & F95 & $\mathrm{F} 50$ & $\mathrm{~F} 5$ & Mean \\
\hline
\end{tabular}

Undiscovered conventional resources in Cotton Valley Group reservoirs within the Jurassic Smackover Interior Salt Basins Total Petroleum System

\begin{tabular}{|c|c|c|c|c|c|c|c|c|c|c|c|c|c|c|}
\hline Oil & 0.5 & 10 & 9.20 & 26.81 & 61.14 & 29.81 & 7.57 & 23.41 & 58.22 & 26.81 & 0.35 & 1.14 & 3.05 & 1.34 \\
\hline Gas & 3.0 & & & & & & 136.46 & 515.29 & $1,220.81$ & 578.22 & 3.93 & 15.30 & 39.31 & 17.66 \\
\hline tal & & 1.00 & 9.20 & 26.81 & 61.14 & 29.81 & 144.03 & 538.69 & $1,279.03$ & 605.03 & 4.28 & 16.44 & 42.36 & 19.00 \\
\hline
\end{tabular}

Cotton Valley Blanket Sandstone Gas Assessment Unit

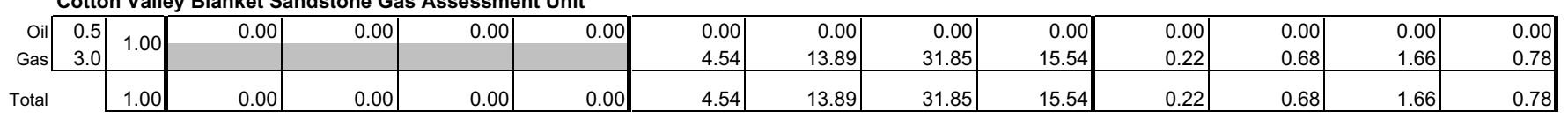

Cotton Valley Massive Sandstone Gas Assessment Unit

\begin{tabular}{|c|c|c|c|c|c|c|c|c|c|c|c|c|c|c|}
\hline Oil & 0.5 & 1.00 & 0.00 & 0.00 & 0.00 & 0.00 & 0.00 & 0.00 & 0.00 & 0.00 & 0.00 & 0.00 & 0.00 & 0.00 \\
\hline Gas & 3.0 & & & & & & 127.40 & 487.62 & $1,157.23$ & 547.25 & 3.58 & 14.22 & 36.65 & 16.42 \\
\hline & & 1.00 & 0.00 & 0.00 & 0.00 & 0.00 & 127.40 & 487.62 & $1,157.23$ & 547.25 & 3.58 & 14.22 & 36.65 & 16.42 \\
\hline
\end{tabular}

Cotton Valley Updip Oil and Gas Assessment Unit

\begin{tabular}{|c|c|c|c|c|c|c|c|c|c|c|c|c|c|}
\hline 0.5 & 100 & 9.20 & 24.42 & 51.44 & 26.70 & 7.57 & 21.43 & 49.17 & 24.02 & 0.35 & 1.04 & 2.58 & 1.20 \\
\hline Gas $\quad 3.0$ & 1.00 & & & & & 4.52 & 13.78 & 31.73 & 15.43 & 0.13 & 0.40 & 0.99 & 0.46 \\
\hline tal & 1.00 & 9.20 & 24.42 & 51.44 & 26.70 & 12.09 & 35.21 & 80.90 & 39.45 & 0.48 & 1.45 & 3.57 & 1.66 \\
\hline
\end{tabular}

Cotton Valley Hypothetical Updip Oil Assessment Unit

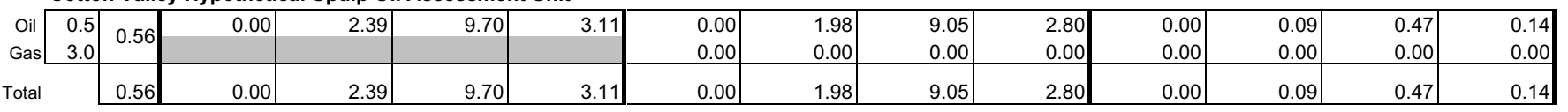

\section{For Further Information}

Geologic studies of total petroleum systems and assessment units and reports on the methodology used in the Cotton Valley Group assessment in the Louisiana-Mississippi Salt Basins Province of the northern Gulf Coast Region are available at the USGS Central Energy Team website:

http://energy.cr.usgs.gov/oilgas/noga

\section{Cotton Valley Group Assessment Team}

T.S. Dyman (Task Leader: dyman@usgs.gov), S.M. Condon, R.R. Charpentier, T.A. Cook, M.D. Lewan, R.M. Pollastro, C.J. Schenk, and J.W. Schmoker. 